\title{
LEMBAR KERJA SISWA (LKS) MATEMATIKA BERBASIS KEMAMPUAN REPRESENTASI MATEMATIS PADA MATERI STATISTIKA
}

\author{
Setiyani \\ Universitas Swadaya Gunung Jati Cirebon \\ email: setiyani_0401509081@yahoo.com
}

\begin{abstract}
ABSTRAK
Representasi merupakan salah satu kemampuan penting yang harus dikembangkan dalam pembelajaran matematika, namundalam kenyataannya kemampuan representasi siswa masih tergolong rendah. Rendahnya kemampuan representasi matematis dapat ditingkatkan melalui pembelajaran yang menggunakan berbagai model, pendekatan, metode, strategi pembelajaran serta bahan ajar. Penelitian ini bertujuan untuk mengembangkan bahan ajar berupa LKS yang dapat menumbuhkan kemampuan representasi matematis siswa. Penelitian ini menghasilkan: bahan ajar berupa LKS matematika terhadap kemampuan representasi matematis pada materi statistika dimana hasil persentase validasi bahan ajar LKS oleh ahli adalah sebesar $94 \%$ yang termasuk dalam kriteria sangat valid yang berarti LKS tersebut layak digunakan dalam pembelajaran materi statistika.
\end{abstract}

Kata Kunci: Representasi Matematis, Statistika, Lembar Kerja Siswa. 


\section{PENDAHULUAN}

Indonesia sebagai negara berkembang, menjelang abad ke-21 dan menghadapi Masyarakat Ekonomi ASEAN (MEA), mengalami persaingan yang luar biasa dalam berbagai bidang, antara lain bidang perekonomian, industri, ilmu pendidikan dan berbagai dimensi lain, baik perkembangan fisik maupun spiritual. Sudah menjadi keharusan bagi negara Indonesia untuk meningkatkan keunggulan dalam berbagai bidang. Indonesia mungkin terkenal dengan tanah surga "Gemah Ripah Loh Jinawi", tapi dalam pasar global surga Sumber Daya Manusia (SDM) lebih dituntut untuk menghadapi pasar global itu sendiri. Oleh karena itu, perlu upaya yang sistematis dilakukan oleh lembaga-lembaga terkait untuk meningkatkan kualitas SDM baik dalam bentuk skill maupun kemampuan berpikir. Kualitas SDM menjadi sangat penting untuk ditingkatkan karena jika tidak, arus tenaga kerja persaingan akan menguasai Indonesia, dan akhirnya yang terbuka adalah lapangan pengangguran untuk rakyat negeri ini. Apabila rendahnya kualitas SDM ini tidak segera diantisipasi, maka warga negara Indonesia hanya akan menjadi konsumen dan penonton setia saja.

Terdapat beberapa cara yang dapat dilakukan untuk meningkatkan kualitas SDM salah satunya melalui peningkatan kualitas proses pendidikan. SMK sebagai salah satu institusi pendidikan kejuruan dituntut untuk mampu menghasilkan lulusan-lulusan siap pakai dan berdaya guna. Lulusan yang diharapkan industri adalah lulusan yang memiliki keterampilan matematika dasar dengan kemampuan konseptual yang dapat tertanam dalam pratek dan dapat diadopsi dalam setiap tempat kerja..Hal ini juga diungkapkan Prihandhika (2017), bahwa matematika penting karena konsep-konsep matematika merupakan bagian dari aktivitas manusia yang kemudian disadari dan dikembangkan menjadi suatu pengetahuan yang selanjutnya digunakan untuk membantu manusia dalam memecahkan masalah. National Council Teacher Matematics
(NCTM, 2000: 67) merekomendasikan lima kompetensi standar yang utama dalam pembelajaran matematika yaitu pemecahan masalah, komunikasi, koneksi, penalaran dan representasi. Salah satu kompetensi standar yang diungkapkan oleh NCTM menjadi fokus dalam penelitian ini adalah kemampuan representasi matematis siswa pada pelajaran matematika, namun hal ini tidak mengabaikan bahwa kemampuan matematis lain yang sama pentingnya.

Menurut Mustangin (2015), representasi dalam konsep matematika sangat berperan dalam pemecahan masalah, khususnya dalam mentransformasikan ide-ide abstrak matematika ke dalam konsep yang lebih nyata misalnya dalam bentuk gambar, simbol, kata-kata, tabel dan lain-lain. Hakikat matematika yang merupakan ilmu abstrak dapat dipermudah dan diperjelas melalui bentuk interpretasi pemikiran siswa dari kemampuan representasinya. Hal ini dapat digunakan sebagai alat bantu terhadap proses solusi suatu masalah, melalui representasi masalah yang semula terlihat sulit menjadi mudah dipecahkan. Namun dalam kenyataan di lapangan, kemampuan representasi matematis masih tergolong rendah mulai dari tingkat siswa ataupun mahasiswa sebagai calon guru. Pernyataan tersebut diperkuat dengan hasil penelitian Noto (2016) yang menyatakan bahwa kemampuan-kemampuan matematis mahasiswa sebagai calon guru matematika juga masih rendah. Hal serupa juga dijumpai pada siswa, studi pendahuluan yang dilakukan peneliti pada tanggal 14 April 2016 di sekolah SMK Islamic Centre Cirebon, yaitu pada siswa kelas XITKJ 1 dengan memberikan soal tes kemampuan representasi matematis berdasarkan indikator (1) membuat situasi masalah berdasarkan data atau representasi yang diberikan, (2) menggunakan representasi visual untuk menyelesaikan masalah, dan (3) menyajikan kembali data atau informasi dari suatu representasi ke representasi diagram, grafik atau tabel.Dari hasil soal uji coba tersebut didapat bahwa siswa belum mampu menyelesaikan soal yang terkait dengan indicator kemampuan 
representasi matematis hal ini ditunjukkan oleh hasil soal uji coba siswa pada materi statistika.Berdasarkan soal uji coba yang diberikan kepada satu kelas yang berjumlah 30 siswa, diperoleh data pada Tabel 1 berikut.

Tabel 1.

Hasil Uji Coba Kemampuan Representasi Matematis

\begin{tabular}{|c|c|c|c|}
\hline \multicolumn{2}{|c|}{$\begin{array}{c}\text { Jumlah Siswa yang } \\
\text { Menjawab }\end{array}$} & \multirow{2}{*}{$\begin{array}{l}\text { Indikator Kemampuan } \\
\text { Representasi Matematis }\end{array}$} & \multirow[t]{2}{*}{ Kesalahan Siswa } \\
\hline Benar & Salah & & \\
\hline 1 & 29 & $\begin{array}{l}\text { Membuat situasi masalah } \\
\text { berdasarkan data atau } \\
\text { representasi yang diberikan. }\end{array}$ & $\begin{array}{l}\text { Siswa masih kurang mampu membuat } \\
\text { situasi atau menyusun cerita dari } \\
\text { perbedaan kedua gambar yang } \\
\text { disajikan. }\end{array}$ \\
\hline 10 & 20 & $\begin{array}{l}\text { Menggunakan representasi } \\
\text { visual untuk menyelesaikan } \\
\text { masalah. }\end{array}$ & $\begin{array}{l}\text { Masih banyak siswa yang keliru } \\
\text { dalam menentukan banyaknya } \\
\text { penjualan handphone yang disajikan } \\
\text { dalam bentuk diagram lingkaran. }\end{array}$ \\
\hline 6 & 24 & $\begin{array}{l}\text { Menyajikan kembali data } \\
\text { atau informasi dari suatu } \\
\text { representasi ke representasi } \\
\text { diagram, grafik atau tabel. }\end{array}$ & $\begin{array}{l}\text { Siswa masih kesulitan membuat } \\
\text { diagram lingkaran karena kesulitan } \\
\text { untuk menentukan derajat dari data } \\
\text { yang disajikan. }\end{array}$ \\
\hline
\end{tabular}

Berdasarkan Tabel 1 di atas terlihat bahwa kemampuan representasi matematis sebagian besar siswa masih rendah. Berikut ini merupakan salah satu hasil uji coba siswa yang ditampilkan pada Gambar 1 di bawah ini.

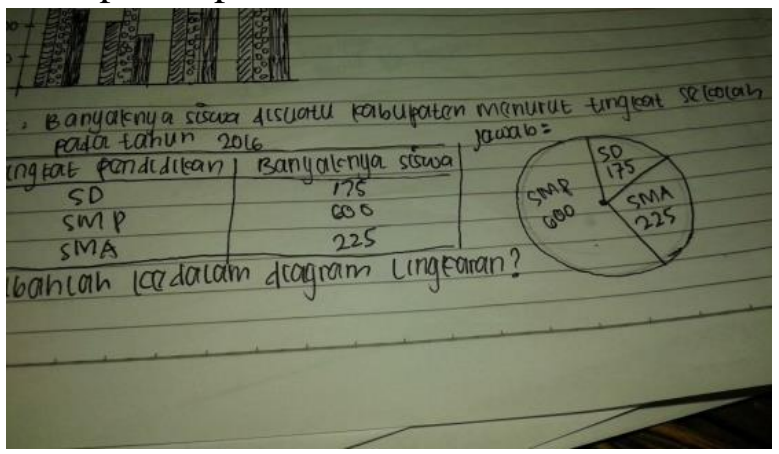

Gambar 1. Jawaban Soal Uji Coba Siswa

Berdasarkan Gambar 1 di atas, siswa kurang tepat dalam menyelesaikan soal yang diberikan. Dari hasil pengerjaan soal tersebut, siswa kurang mampu menyajikan kembali data atau informasi dari suatu representasi ke representasi diagram, grafik, atau tabel. Sebagian besar siswa mengerjakan soal tersebut dengan cara menyajikan secara langsung nilai yang disajikan dari bentuk tabel ke dalam bentuk diagram lingkaran. Siswa cenderung kurang mampu untuk menentukan terlebih dahulu sudut juring dan persentase dari data yang yang disajikan dalam diagram tabel tersebut.

Salah satu penyebab rendahnya kemampuan representasi siswa adalah proses pembelajaran yang dilakukan oleh guru di dalam kelas kerap tidak melibatkan siswa. Aktivitas siswa lebih cenderung menerima materi, mencatat, dan berlatih soal-soal matematika. Interaksi antara guru dengan siswa atau siswa dengan siswa kurang berjalan dengan baik. Kemampuan representasi siswa pun bukanlah menjadi poin prioritas untuk ditumbuhkan apalagi dikembangkan. Selain itu, selama ini media pembelajaran yang digunakan hanya slide presentasi menggunakan power point. Buku ajar yang dipakai pun hanya dari pemerintah saja. Selama ini guru belum pernah mengembangkan atau menyusun bahan ajar sendiri. Keterbatasan media pembelajaran ini berdampak pada pembelajaran yang pada akhirnya hanya satu arah, yaitu dari guru ke siswa. Siswa masih belum dapat mengoptimalkan kemampuan representasinya dalam memecahkan suatu permasalahan yang dihadapi. 
Diperlukan solusi untuk mengatasi permasalahan tersebut, maka perangkat pembelajaran yang mendukung harus di desain secara tepat dengan perencanaan yang matang. Untuk itu pengembangan LKS berbasis kemampuan representasi matematis siswa dapat dijadikan sebagai alternatif dalam menyelesaikan masalah tentang keterbatasan bahan ajar dan rendahnya aktivitas yang mendukung peningkatan kemampuan representasi matematis siswa. Dengan demikian, penulis memberikan sebuah alternatif pembelajaran yaitu suatu desain bahan ajar yang berupa Lembar Kerja Siswa (LKS). Sumber belajar berupa bahan ajar merupakan salah satu kunci untuk menentukan keberhasilan implementasi kurikulum 2013 yang direvisi. Sehingga perangkat pembelajaran khususnya bahan ajar harus dikembangkan untukmeningkatkan kualitas pembelajaran. LKS yang dikembangkan haruslah menarik agar siswa tidak merasa bosan ketika membaca materi yang sedang diajarkan. Hal itu didukung oleh Arafah, dkk. (2012) yang menunjukkan bahwa bahan ajar berupa LKS yang disusun membuat pembelajaran lebih menarik sehingga pada evaluasi akhir ketuntasan belajar siswa mengalami kenaikan. Respons yang positif akan diperoleh apabila siswa sudah tertarik dan terlibat dalam proses pembelajaran. Selain menarik, bahan ajar juga harus merupakan bahan ajar yang valid. Maka dari itu, sebelum diberikan kepada siswa, bahan ajar tersebut perlu divalidasi terlebih dahulu. Begitu pula dengan instrumen yang ada dalam bahan ajar tersebut. Sebelum soal instrumen diberikan kepada siswa, terlebih dahulu dilakukan pengujian validitas butir soal, reliabilitas butir soal, daya pembeda tiap butir soal, dan indeks kesukaran tiap butir soal.

Berdasarkan uraian di atas, maka penulis berminat untuk meneliti lebih lanjut mengenai "Lembar Kerja Siswa (LKS) Berbasis Kemampuan Representasi Matematis Siswa pada Materi Statistika”.

\section{METODE PENELITIAN}

Penelitian ini termasuk penelitian pengembangan (Research and Development). Perangkat pembelajaran yang dikembangkan dalam penelitian ini adalah bahan ajar berupa LKS materi statistika berbasis kemampuan representasi matematis dengan mempertimbangkan keragaman respons siswa. Seperti halnya yang diungkapkan Noto (2014), bahwa pengembangan perangkat harus disesuaikan dengan memperhatikan kekhususan materi dan tingkat kemampuan siswa (spesifik). Perangkat pembelajaran yang dikembangkan menggunakan model pengembangan 4-D Thiagarajan yang dimodifikasi ini melalui serangkaian tahap pengembangan yakni tahap pendefinisian, perancangan, pengembangan hingga penyebaran (Muchayat, 2011). Pengembangan perangkat tersebut melalui proses validasi dari 5 ahli (validator), kegiatan revisi pertama hingga diperoleh Draft, kegiatan ujicoba, dan analisis serta revisi berdasarkan hasil ujicoba hingga diperoleh perangkat final yang valid. Diagram alir pengembangan perangkat pembelajaran modifikasi 4D yang telah disederhanakan menjadi 3 tahap dapat dilihat pada Gambar 2 berikut.

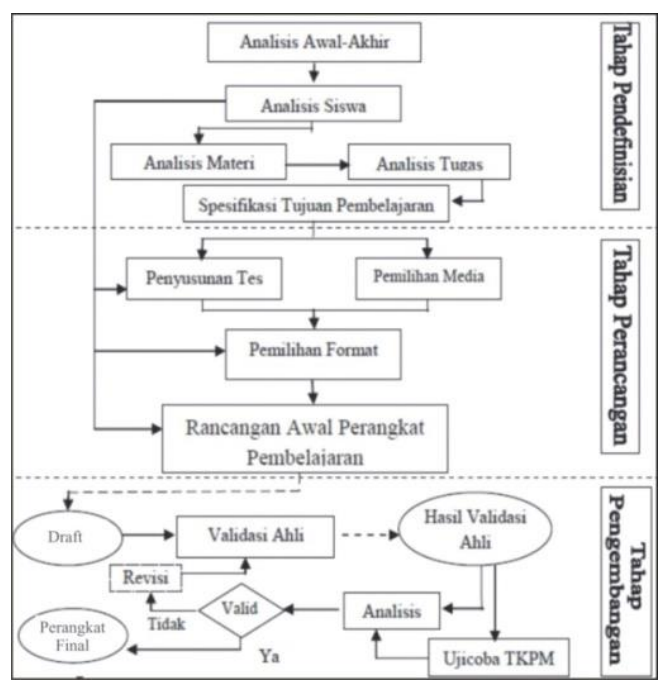

Gambar 2. Modifikasi Pengembangan Perangkat Model 4-D 


\section{Prosedur Penelitian dan Pengembangan}

\section{a. Tahap Define}

Tahap pendefinisian (define) adalah untuk menentukan dan menegaskan kebutuhan-kebutuhan pembelajaran. Langkah-langkah yang dilakukan dalam tahap ini adalah: (1) analisis ujung depan yang mengarah pada hasil akhir dari pengembangan yakni berupa LKS statistika yang berbasis kemampuan representasi, (2) analisis siswa, langkah ini menetapkan subyek pebelajar dan sasaran belajar siswa yaitu siswa kelas $\mathrm{X}$ semester 1 dengan materi pokok statistikadan (3) perumusan indikator hasil belajar yang dirumuskan berdasarkan standar kompetensi dan kompetensi dasar pada kurikulum 2013. Analisis siswa dibedakan menjadi dua, yaitu: (1) analisis tugas dengan mencari literatur dan sumber belajar tentang statistika dan (2) analisis konsep yang dilakukan dengan mengidentifikasi konsepkonsep utama yang akan dipelajari. Tahapan define ini diakhiri dengan spesifikasi tugas yang diperoleh melalui serangkaian kegiatan di atas.

\section{b. Tahap Design}

Tahap perencanaan (design) meliputi tiga langkah yaitu: (1) penyusunan LKS dengan membuat soal yang bertujuan untuk mengetahui tingkat pemahaman materi dan keberhasilan siswa dalam memahami materi dalam bahan ajar, (2) pemilihan media untuk mendapatkan media yang tepat sesuai dengan perkembangan era teknologi yang sedang berlangsung, yaitu media internet, dan (3) perancangan awal yang meliputi membaca buku teks yang relevan, menulis LKS, adaptasi LKS, konsultasi secara intensif dengan dosen mitra (pengampu mata kuliah multimedia pembelajaran dan statistika) dan beberapa guru matematika.

\section{c. Tahap Develop}

Pada tahap pengembangan (develop) langkah- langkah yang dilakukan adalah: (1) konsultasi dengan dosen mitra yang bertujuan untuk merancang dan menyusun media dan instrumen yang akan dipakai dalam penelitian, (2) validasi yang merupakan kegiatan untuk mengumpulkan data tentang nilai yang diperoleh dari validator, (3) analisis hasil validasi, hasil validasi dianalisis sesuai dengan penilaian, saran, dan kritik dari validator, (4) revisi LKS yang bertujuan untuk menyempurnakan bahan ajar yang akan digunakan, dan (5) uji coba terbatas, tujuan uji coba ini hanya untuk mengetahui kelayakan dari produk pengembangan yakni LKS.

\section{Instrumen Pengumpulan Data}

Instrumen penelitian yang akan dikembangkan meliputi lembar validasi. Instrumen pengumpulan data adalah alat bantu yang dipilih dan digunakan oleh peneliti dalam pelaksanaan pengumpulan data. Dalam penelitian ini instrumen pengumpulan adalah lembar validasi. Salah satu kunci dari pengembangan perangkat adalah penilaian validasi ahli.Penilaian validasi dilakukan untuk mengetahui apakah hasil rancangan (draft) perangkat pembelajaran matematika yang dikembangkan benar-benar valid. Lembar validasi bahan ajar merupakan suatu media untuk penilaian tehadap bahan ajar berupa LKS yang disusun oleh peneliti. Validasi ini bertujuan untuk mengetahui tingkat validitas bahan ajar atau sebagai upaya untuk menghasilkan bahan ajar dengan validitas yang baik. Lembar validasi bahan ajar ini diberikan kepada dosen sebagai validator dari bahan ajar. Instrumen validasi yang digunakan dalam validasi bahan ajar LKS matematika ini dapat dilihat pada Tabel 2 berikut.

Tabel 2.

Instrumen Validasi Lembar Kerja Siswa (LKS) oleh Para Ahli

\begin{tabular}{llll}
\hline \multirow{2}{*}{ Indikator/Aspek yang Divalidasi } & \multicolumn{3}{c}{ Skor } \\
\cline { 2 - 4 } & & & 2 \\
\hline prinsip bahan ajar menurut depdiknas & & & \\
\hline terdapat prinsip relevansi & & \\
\hline terdapat prinsip konsistensi & & \\
\hline terdapat prinsip kecukupan & & \\
\hline
\end{tabular}




\begin{tabular}{lll}
\hline Indikator/Aspek yang Divalidasi & \multicolumn{2}{c}{ Skor } \\
\cline { 2 - 2 } kemampuan representasi matematis & & \\
\hline terdapat kemampuan representasi matematis & \\
\hline Konten bahan ajar & \\
\hline isi LKS akurat & \\
\hline LKS komunikatif & \\
\hline kelengkapan LKS & \\
\hline bahasa yang digunakan dalam bahan ajar sesuai dengan Bahasa \\
Indonesia yang baik dan benar \\
\hline LKS memiliki daya tarik \\
\hline ketepatan bentuk dan ukuran huruf \\
\hline
\end{tabular}

Setelah memperoleh jumlah skor dari hasil validasi yang dilakukan para ahli, selanjutnya menurut Akbar (2013: 82) untuk mengetahui validitas bahan ajar modul tersebut dengan cara sebagai berikut:

$$
\begin{aligned}
v_{n}=\frac{\sum(\text { jawaban } \times \text { bobot tiap pilihan })}{n} \times \text { bobot tertinggi } \\
\times 100 \%
\end{aligned}
$$

Adapun di bawah ini adalah Tabel 3 yang merupakan kriteria validasi yang diperoleh dari perhitungan di atas adalah sebagai berikut.

Tabel 3.

Kriteria Validasi Bahan Ajar Modul oleh

\begin{tabular}{|c|c|}
\hline Kriteria Validitas & Tingkat Validitas \\
\hline $85,01 \%-100 \%$ & $\begin{array}{l}\text { Sangat valid, atau } \\
\text { dapat dugunakan } \\
\text { tanpa revisi }\end{array}$ \\
\hline $70,01 \%-85,00 \%$ & $\begin{array}{l}\text { Cukup valid, atau } \\
\text { dapat digunakan } \\
\text { dengan revisi }\end{array}$ \\
\hline $50,01 \%-70,00 \%$ & $\begin{array}{ll}\text { Kurang } & \text { valid, } \\
\text { disarankan } & \text { tidak } \\
\text { dipergunakan } & \\
\text { karena perlu revisi } \\
\text { besar }\end{array}$ \\
\hline $01,00-50,00 \%$ & $\begin{array}{l}\text { Tidak valid, atau } \\
\text { tidak boleh } \\
\text { dipergunakan }\end{array}$ \\
\hline
\end{tabular}
Para Ahli

\section{HASIL DAN PEMBAHASAN}

A. Deskripsi Hasil Pengembangan LKS

LKS pengembangan yang telah dibuat terdiri dari beberapa komponen yang dapat disajikan sesuai dengan kaidah pengembangan LKS. Adapun uraian lebih lanjut sebagai berikut:

1. Halaman Judul, terdiri dari judul LKS dan Penulis. Berikut adalah tampilan pada halaman judul.

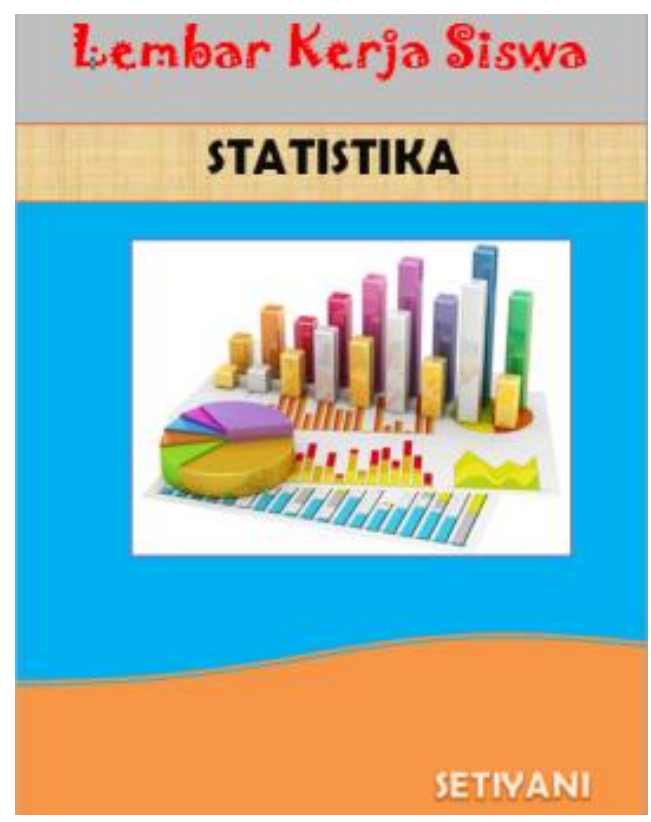

\section{Gambar 3. Halaman Judul pada LKS}

2. Pengantar bab, terdiri dari petunjuk penggunaan isi LKS, kompetensi dasar, indikator pembelajaran dan indikator kemampuan representasi matematis. Berikut adalah gambar dari pengantar bab yang terdapat di dalam LKS. 


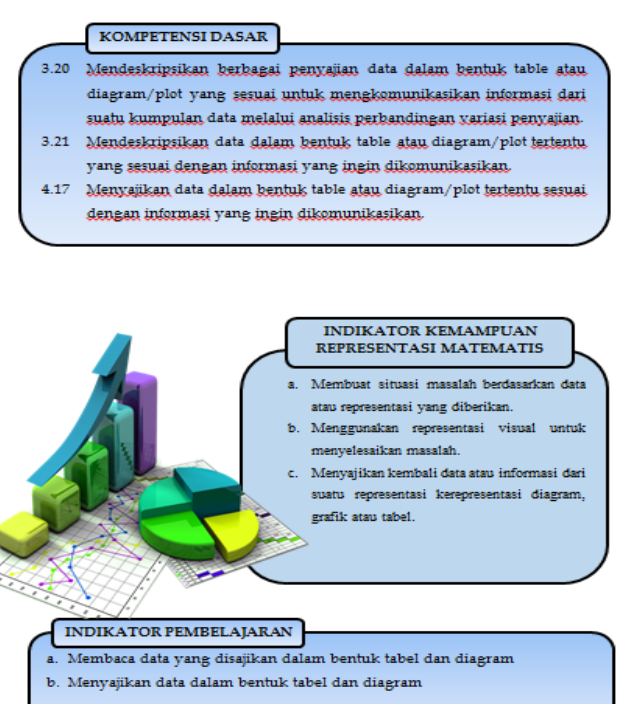

Gambar 4. Pengantar Bab pada LKS

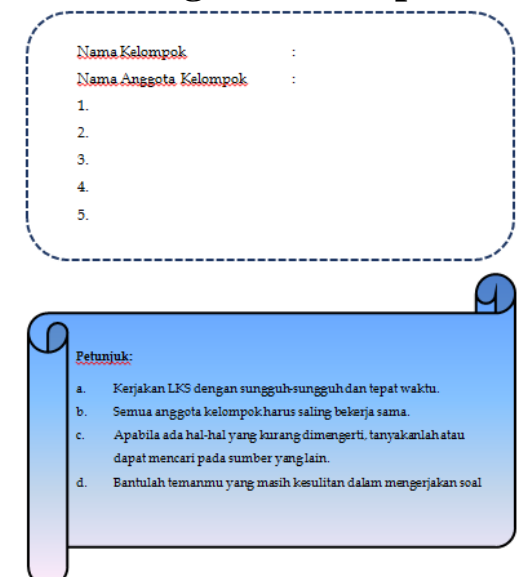

\section{Gambar 5. Petunjuk Latihan pada LKS}

3. Peta konsep berisi keterkaitan antar materi di Bab Statistik. Berikut adalah tampilan peta konsep pada LKS.

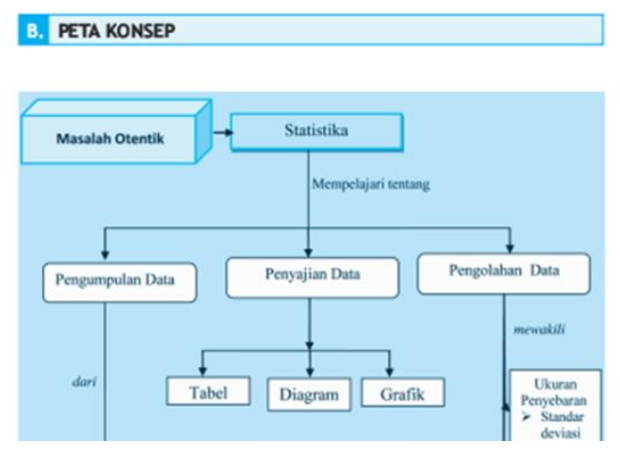

Gambar 6. Peta Konsep pada LKS

4. Isi materi terdiri dari materi-materi yang terdapat di Bab Statistika, contoh soal, dan lembar kerja siswa. Berikut adalah tampilan isi materi yang terdapat di dalam LKS.
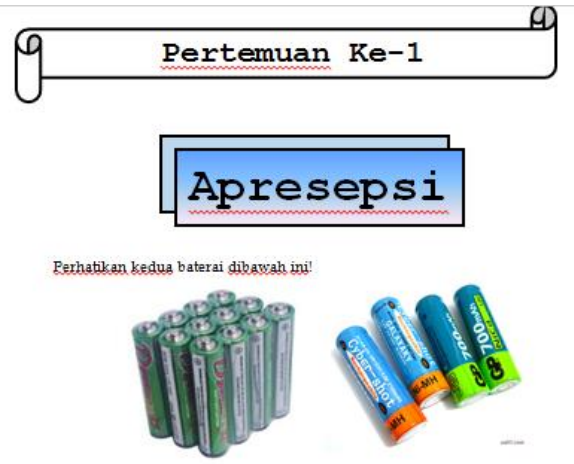

Dya Rerusahaan memuxoduksi. baterai dan masing-masing perusahaan. meneklaim bahrsa produknxalebirhbagus dan tahanlama Berhubunean denean

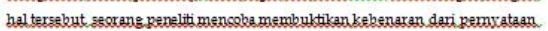
sedua nerusehann tersebut.

Gambar 7. Apresepsi pada Setiap Sub

\section{Pokok Bahasan}

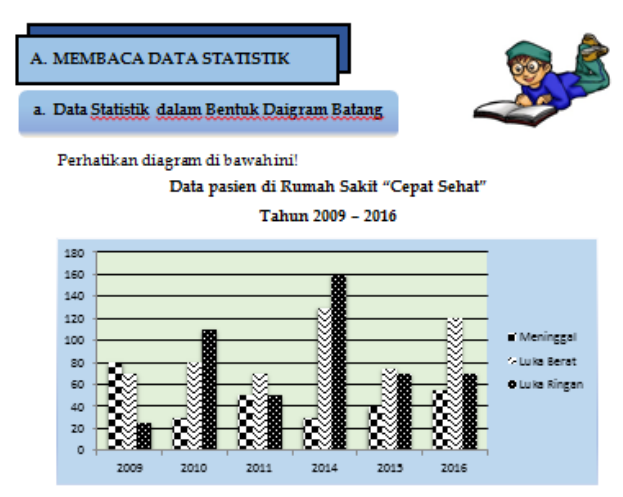

Pada diagram batang di atas, batang dilukiskan sebagai balok hergaris. Garis menyatakan banyaknya orang yang meninggal, garis 0 menyatakan orang yang luka berat, dan garis

\section{Gambar 7. Isi Materi}

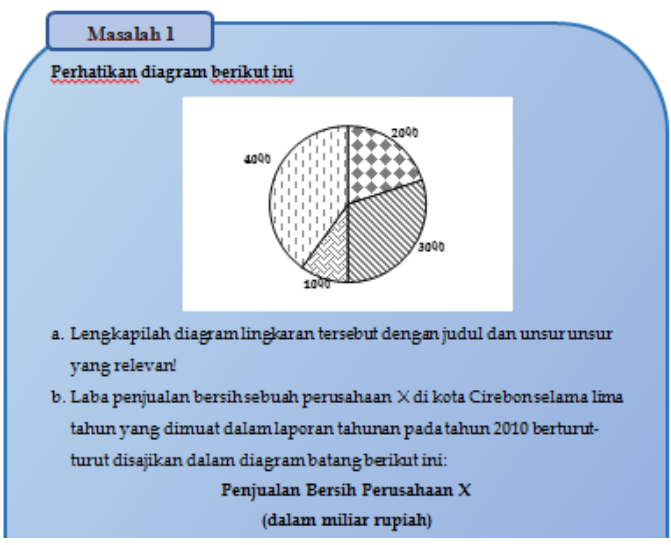

\section{Gambar 8. Masalah Representasi Matematis}

5. Penutup bab terdiri dari rangkuman dan daftar pustaka. Berikut adalah tampilan penutup bab yang terdapat di dalam modul. 


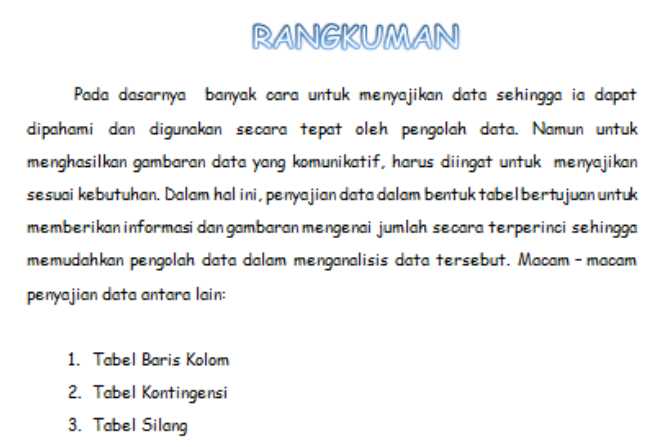

Gambar 9. Rangkuman Pada LKS

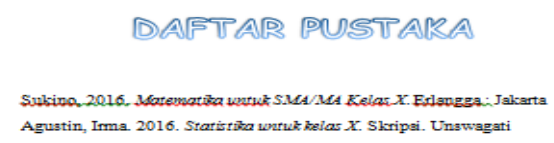

Gambar 10. Daftar Pustaka

\section{B. Pembahasan Validasi Berdasarkan data Kualitatif}

Adapun data kualitatif yang dihimpun berdasarkan masukan, saran dan komentar ahli dalam pernyataan terbuka yang berkenaan dengan LKS diketahui dari tabel berikut ini :

Tabel 4. Kritik dan Saran Validator

\begin{tabular}{|c|c|}
\hline Nama Validator & Kritik dan Saran \\
\hline Anggita & 1. Dibuat peta konsep \\
\hline Maharani, M.Pd & $\begin{array}{l}\text { 2. Perhatikan tata tulis } \\
\text { 3. Soal statistika harus } \\
\text { lebih variatif }\end{array}$ \\
\hline $\begin{array}{l}\text { Nurul Ikhsan } \\
\text { Karimah, S.Si., } \\
\text { M.Pd }\end{array}$ & $\begin{array}{ll}\text { 1. } & \text { Daftar pustaka } \\
\text { jangan } 1 \text { sumber } \\
\text { 2. Tanda baca } \\
\text { 3. Soal- soal harus } \\
\text { sesuai dengan } \\
\text { kemampuan } \\
\text { representasi } \\
\text { matematis }\end{array}$ \\
\hline
\end{tabular}

Berdasarkan hasil validasi ahli, beberapa revisi yang dilakukan terdapat bahan ajar dapat dilihat pada Tabel 5 berikut.

Tabel 5.

Revisi LKS Berdasarkan Komentar dan Saran Validator

LKS Sebelum Revisi

Tata tulis (tanda baca) pada LKS Tata tulis (tanda baca) pada LKS sudah diperbaiki belum sempurna

\begin{tabular}{ll}
\hline Sebaiknya dibuat peta konsep & Peta konsep \\
\hline $\begin{array}{l}\text { Soal statistika lebih bervariatif } \\
\text { dan sesuai dengan kemampuan } \\
\text { representasi }\end{array}$ & $\begin{array}{l}\text { Soal sudah lebih variatif dengan memunculkan soal } \\
\text { dalam kehidupan nyata siswa dan memenuhi beberapa } \\
\text { indikator kemampuan representasi yang menjadi } \\
\text { fokus pada penelitian ini. }\end{array}$ \\
\hline $\begin{array}{l}\text { Daftar pustaka harus lebih dari } \\
\text { satu }\end{array}$ & Daftar pustaka sudah lebih dari satu \\
\hline
\end{tabular}

\section{Pembahasan Validasi Berdasarkan Data Kuantitatif}

Berdasarkan hasil dari perhitungan, maka hasil dari penilaian dua validator yang masing-masing menunjukkan bahwa bahan ajar berupa LKS yang telah disusun peneliti sudah memenuhi ketentuan atau bisa dikatakan sudah valid. Hasil validasi bahan ajar LKS terhadap kemampuan representasi matematis didasarkan pada hasil rata-rata penilaian para validator diperoleh hasil validasi LKS diperoleh 94\% dengan kriteria sangat valid. Dari hasil validasi tersebut, dapat disimpulkan bahwa pengembangan LKS yang akan diimplementasikan tidak memerlukan revisi yang signifikan. Akan tetapi, peneliti perlu memperhatikan komentar dan saran yang telah diberikan oleh validator. Dengan demikian, peneliti perlu melakukan beberapa revisi terhadap LKS sebelum diimplementasikan.

Berdasarkan hasil penelitian yang telah dilaksanakan, terdapat beberapa saran dalam rangka perbaikan proses penelitian selanjutnya, yakni sebagai berikut: 
1. LKS yang telah disusun oleh peneliti untuk menjadi salah satu alternatif pembelajaran pada materi statistika untuk menumbuhkembangkan kemampuan representasi matematis siswa

2. Penelitian ini hanya terbatas sampai tahap pengembangan saja, untuk penelitian selanjutnya perlu dilakukan implementasi untuk menguji ke efektifan LKS ini dalam proses belajar mengajar.

\section{DAFTAR RUJUKAN}

Akbar, Sa'adun. (2013). Instrumen Perangkat Pembelajaran. Jakarta : PT Remaja Rosdakarya

Arafah, dkk. (2012). Pengembangan LKS Berbasis Berpikir Kritis pada Materi Animalia. Unnes Journal of Biology Education 1(1), 47-53.

Muchayat. (2011). Pengembangan Perangkat Pembelajaran Matematika Dengan Strategi Ideal Problem Solving Bermuatan Pendidikan Karakter. JURNAL PP VOLUME 1, NO. 2, DESEMBER 2011. Pp 200-208.

Mustangin. (2015). Representasi Konsep dan Peranannya dalam Pembelajaran Matematika Sekolah. Jurnal Pendidikan Matematika Vol.1, No. 1: 15-21. Malang: Prodi Pendidikan Matematika FKIP UIM.

NCTM. (2000). Principles and Standards for School Mathematics. Reston Virginia: NCTM.

Noto, M. S. (2014). Perangkat Pembelajaran Matematika Berbasis Smart (Specific, Measurable, Achievable, Realistic, And Time-Bound). InfinityJurnal Vol 3, No.1, Hal. 1832.

Noto, M. S. (2016). Profil Kemampuan Penalaran, Spasial dan Koneksi Matematis Mahasiswa Calon Guru Matematika. Prosiding Seminar
Nasional Matematika dan Pendidikan Matematika (SNMPM) 2016 dengan Tema: Strategi Mengembangkan Kualitas Pembelajaran Matematika Berbasis Riset. Hal. 293-305

Prihandhika, A. (2017). Perbedaan Kemampuan Koneksi Matematis Melalui Model Pembelajaran REACT dengan Model Pembelajaran Learning Cycle 5E Siswa SMKN 39 Jakarta.JNPM (Jurnal Nasional Pendidikan Matematika) Vol. 1, No.1, Hal.1-9 


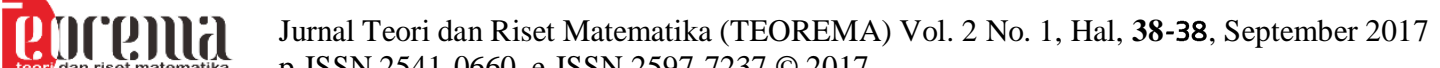
p-ISSN 2541-0660, e-ISSN 2597-7237 @ 2017 